\title{
CONTRASTING GEOMETRY BETWEEN ALPINE AND LATE- TO POST- ALPINE TECTONIC STRUCTURES IN ANAFI ISLAND (CYCLADES)
}

\author{
Konstantinos. I. Soukis and Demetrios. J. Papanikolaou \\ Dynamic, Tectonic and Applied Geology Department of Geology, National Kapodistrian \\ University of Athens, soukis@geol.uoa.gr, dpapan@geol.uoa.gr
}

\section{ABSTRACT}

A significant change is observed in the geometry of the major faults in Anafi Island from $\mathrm{N}$ to NE dip in the alpine structures to $S$ to SW dip in the late to post-alpine.

Several thrust faults dipping to the NE preserved at the central-eastern part of the island form a nappe pile of Cretaceous HT/LP metamorphic units emplaced over a parautochthonous nonmetamorphic flysch of partly Eocene age without development of metamorphic structures (deformation phase $\mathrm{D}_{1}$ ).

The development of detachment normal faults dipping to the SW (deformation phase $D_{2}$ ) deformed the previous thrusts together with the post alpine continental sedimentary sequence of Miocene age, occurring in the northern and western part of Anafi. Asymmetric to the SW folds are observed at the lower part of the Upper Miocene sediments as well as numerous shear sense indicators along the undulating surface of the detachment above the underlying alpine units. The deformation weakens towards the upper part of the Upper Miocene sediments. An intensely sheared molassic type formation of probable ?Oligocene-Early Miocene age was distinguished between the alpine units and the detached Upper Miocene sediments. High angle normal faults dipping to the SW deform all previous structures $\left(D_{3}\right)$.

The extensional deformation phases $D_{2}$ and $D_{3}$ are related to the opening of the Cretan backarc basin during Tortonian - Early Pliocene.

\section{INTRODUCTION}

The transition from compression to extension within an orogenic arc system with inward dipping thrusts followed by outward-opposite dipping detachment normal faults is illustrated in the case of Anafi Island, Cyclades. More precisely, NE dipping thrusts building an alpine nappe pile with shear sense towards the SW are followed by low-angle detachment normal faults dipping to the SW with shear sense again to the SW. This SW direction of tectonic transport in the case of the Hellenic arc is normal to its trend and demonstrates a constant $\sigma_{1}-\sigma_{3}$ stress plane from Late Eocene-Oligocene to Late Miocene.

The preservation of both types of tectonic geometry (compressional and extensional) with opposite dipping structures is rather rare especially when syntectonic sediments are also present as in the case of Anafi.

\section{GEOLOGICAL SETTING}

Anafi Island is located at the southeastern edge of the Atticocycladic metamorphic core complex, north of the Cretan back-arc basin (Fig. 1a). Although it is a very small island, it shows a remarkable lithological variety, comprising metamorphosed and non-metamorphosed alpine units as well as post-alpine sediments (Fig. 1b). 


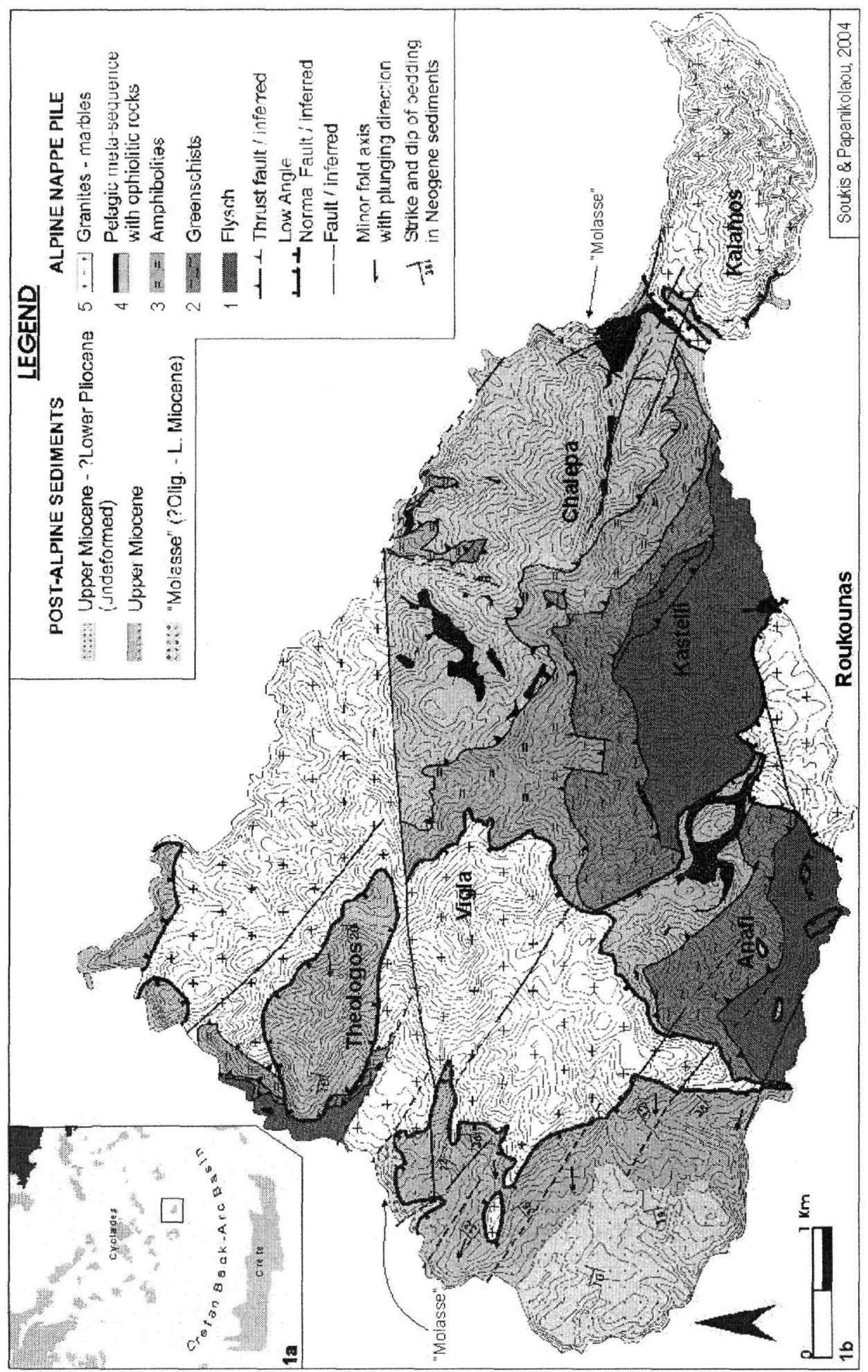

Figure 1. (a) Anafi Island is located at the southeastern edge of the Cycladic metamorphic core complex; (b) Geological map of Anafi Island (modified after Melidonis 1963 and Reinecke et al. 1982). 


\subsection{Alpine units}

The alpine units include a parautochthonous non-metamorphosed flysch and slices of crystalline rocks that form a metamorphic nappe pile over the flysch. The succession of tectonic units from the lower to the upper is as follows:

1. The parautochthonous flysch of partly Eocene age (Melidonis 1963) can be mainly observed at the southern part of the island (Fig 1b). The lower part comprises sandstones, pelites and slates and the upper part conglomerates with pebbles of dark-colored carbonates, basic volcanic rocks, ophiolites and recrystallised light-colored marbles different from the marbles of the overlying alpine units. Reinecke et al (1982), attributed this flysch to the clastic formation seen below the upper unit in Crete, however it could be also correlated to the flysch of the neighboring Thera and Astypalaea Islands, which is considered as part of the External Hellenides carbonate platform (Papanikolaou 1987).

2. Isoclinally folded fine grained greenschists tectonically overlying the parautochthonous flysch (typical mineral assemblage: albite + chlorite + epidote \pm quartz \pm sphene \pm opaques \pm white mica). According to Reinecke et al (1982) these rocks show MORB affinities and K-Ar dating on actinolites yielded cooling ages around $62 \mathrm{Ma}$.

3. Massive to platy amphibolites metamorphosed in a higher metamorphic grade than the underlying greenschists (typical mineral assemblage: hornblende + andesine/oligoclase \pm quartz \pm sphene \pm apatite \pm magnetite \pm ilmenite \pm sulfides). The chemical composition of the amphibolites is similar to back-arc basin tholeiites (Reinecke et al 1982).

4. A pelagic to oceanic sequence of meta-sediments located at the northeastern part of the island that includes platy marbles, metachert-bearing marbles, impure marbles with ophiolitic detritus, schists and paragneisses metamorphosed in close association with ophiolitic rocks and dioritic intrusive rocks.

5. Thick-bedded coarse-grained marbles and large bodies of acid intrusives indicating a palaeomagmatic arc environment (Reinecke et al 1982). This unit includes the I- and S-type granitic rocks located mainly at the western and northern part of the island and the marbles of Kalamos at the eastern part of the island.

$\mathrm{K}-\mathrm{Ar}$ dating on hornblendes and biotites of the higher metamorphic grade units (e.g. the amphibolites, the pelagic meta-sequence and the granitic rocks) yielded cooling ages between 69 and 63 Ma (Reinecke et al 1982).

\subsection{Alpine thrusts}

Several NW-SE trending thrust faults can be observed at the central-eastern and the southern parts of Anafi Island separating the alpine units, including the basal tectonic contact between the non-metamorphosed parautochthonous flysch and the overlying greenschsists.

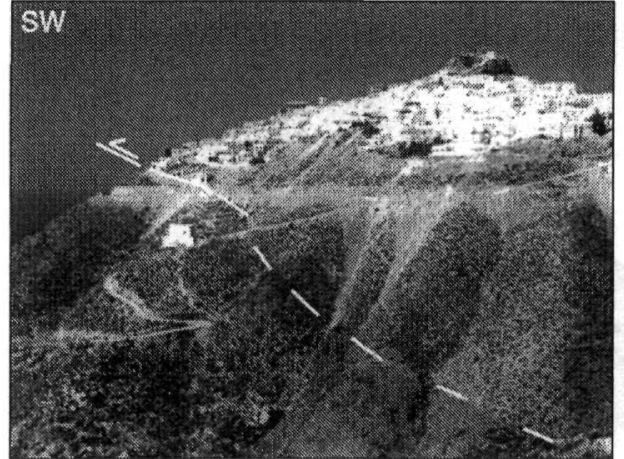

Figure 2a. Thrust fault dipping moderately towards the NE and juxtaposing the underlying flysch (dark color) and the overlying greenschists (light color).

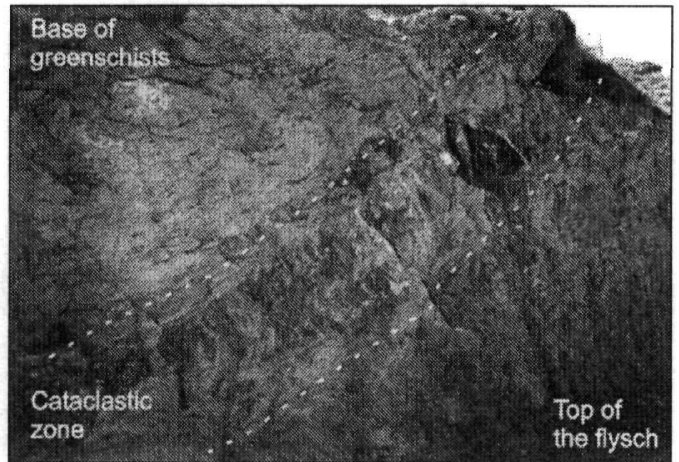

Figure $2 \mathrm{~b}$. Detail of the thrust fault that emplaces tectonically the greenschists (upper left) over the flysch (lower right) with the $1,5 \mathrm{~m}$ thick cataclastic zone. 

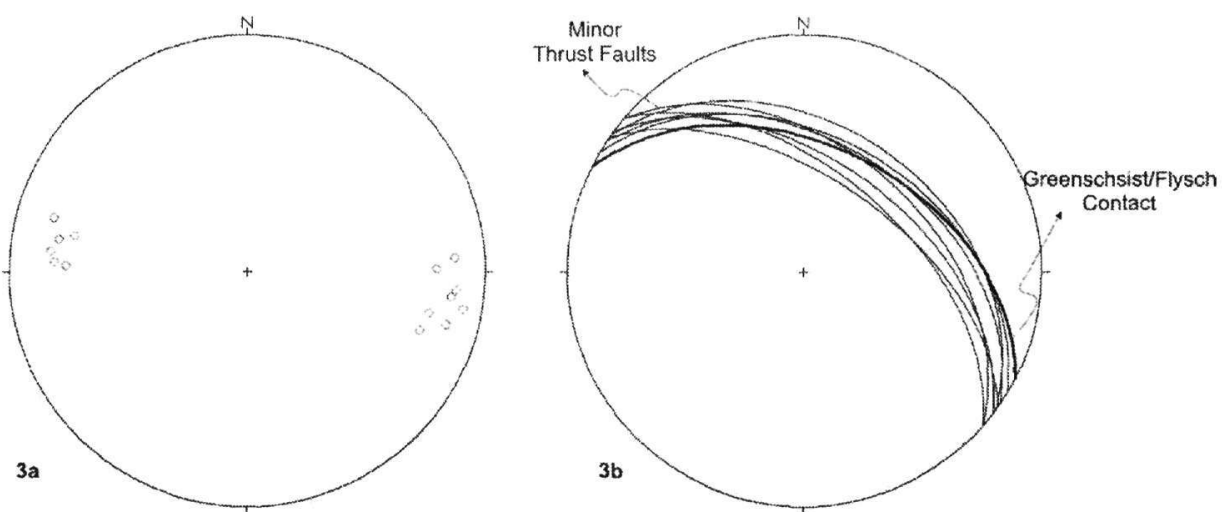

Figure 3. a) Stereographig projection of B-fold axes observed in the flysch. b) Major thrust fault juxtaposing the greenschists over the flysch and associated minor thrust faults observed at the top of the flysch at Kastelli area (see fig1).

The contact between the flysch and the overlying greenschists is a thrust fault dipping moderately - steeply towards the NE (Fig 2a). Cataclastic deformation prevails along the contact indicating that thrusting took place at shallow structural level. Local shearing is accompanied with s-planes of fracture or slaty cleavage depending on the lithology. These brittle deformation s-surfaces overprint the schistosity of the greenschists and the bedding planes of the flysch resulting in a foliated cataclasitic zone (Fig 2b). Tectonic emplacement of the overlying metamorphic units is associated with WNW-ESE trending tight to isoclinal folds observed in the Eocene flysch (Fig 3a). Axial planes of these folds as well as fracture cleavage dip moderately-to-steeply towards NE. At the area of Kastelli thrusting of the greenschists on the flysch has caused imbrications of the top most flysch with kinematic indicators of top-to-the SW transport (deformation phase $D_{1}$ Fig $3 b$ ).

Similar features are also observed along the higher thrust faults separating the metamorphic units (Greenschists - Amphibolites - Pelagic meta-sequence with ophiolites - Marbles and Granites) with dip moderately towards the northeast and few meters thick zones of tectonic breccia and brittle deformation structures. Tectonic transport indicated by these tectonic contacts is also top-tothe-SW.

\subsection{Late and Post-alpine sediments}

The late and post-alpine sediments are observed at the northern and western parts of the island and can be differentiated in the following formations:

- A molasse-type formation comprising intensely sheared clastic sediments and less deformed conglomerates with pebbles of HP/LT metamorphic rocks not reported in Anafi. This formation is observed in two outcrops: at the northwestern part of the island where it is overlain tectonically by the post-alpine sediments and at the eastern-southeastern part of the island where it is bounded by normal faults (Fig 1b). Reinecke et al. (1982) assigned these outcrops to the parautochthonous flysch but this is contradicted by their tectonic position over the metamorphic nappes of Anafi (granites and marbles - unit 5- in the northwest and meta-sediments with ophiolites -unit 4- in the east). We suggest that it represents a molassic-type formation of probable ?Oligocene - Early Miocene age, similar to that described in the Cyclades (Dermitzakis \& Papanikolaou 1981, Papanikolaou 1987) involved in the Late Miocene tectonism.

- A post-alpine succession of fluvial to lacustrine clastic sediments with limestone and marl intercalations of Late Miocene -?Early Pliocene age (determined by ostracodes, Boger 1983). The succession is divided into two parts on the basis of deformation. The lower deformed part reaches up to $250 \mathrm{~m}$ thickness (Theologos hill, see fig 1) and comprises red shales, sandstones, marls and few limestone intercalations. The upper part is located at the southwestern part of the island and overlies unconformably the lower part. It comprises almost undeformed marls and calcareous clastic sediments that exceed $100 \mathrm{~m}$ of thickness. 


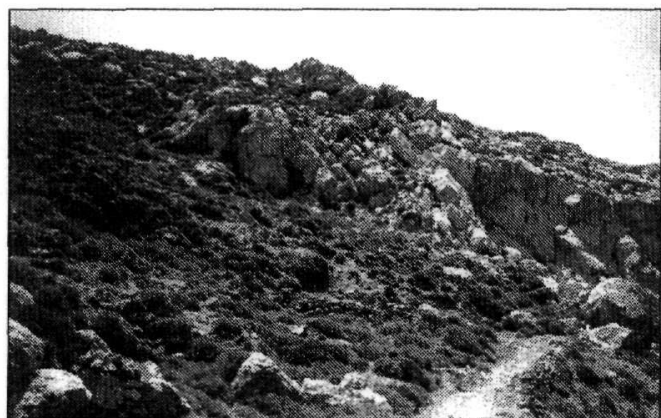

Figure 4a. Low-angle normal fault located at Kalamos area juxtaposing ophiolites of unit 4 in the footwall and marbles of unit 5 in the hanging wall.

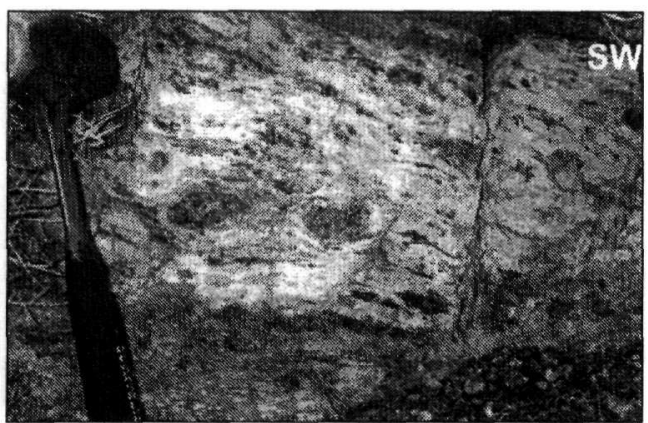

Figure $4 \mathrm{~b}$. Clasts with asymmetric tails in foliated cataclasites of the footwall metasediments in Kalamos area indicate sense of shear top-to-the-SW.

\subsection{Late-alpine structures}

The previous compressional structures of deformation phase $D_{1}$ are disrupted by low-angle normal faults generally dipping to the SW that is opposite to the NE dipping thrusts. The late-alpine extensional structures of $D_{2}$ deformation phase are observed either within the alpine nappe pile or between the Miocene sediments and the alpine units. In the first case the characteristic of the lowangle normal fault is the omission of some intermediate units with the higher units 4 and 5 lying directly over the lower unit 1 . In the second case the Miocene sediments are tectonically overlying the alpine units through a detachment normal fault.

Low-angle normal faults within the alpine units are observed at the eastern (Kalamos), southern (Roukounas) and western parts of the island (Vigla). At Kalamos area the contact between the top alpine unit 5 and the underlying unit 4 is a SSE-dipping major low-angle normal fault that juxtaposes coarse - grained marbles and acid intrusives of unit 5 against the metasediments and ophiolites of unit 4 (Fig 4 a). Brittle deformation prevails in the hanging wall marbles and footwall rocks exhibit strong cataclastic deformation. Clasts with asymmetric tails observed below the fault surface indicate top-to-SW sense of shearing (Fig $4 \mathrm{~b}$ ). Two generations of striations on minor splay faults record right-lateral and dip slip movement. Footwall metasediments crop out along the southern coast of Kalamos indicating that the fault surface is undulated.

Along the southern coast of the island several isolated outcrops of the higher alpine units $(4,5)$ are juxtaposed against the lower units of the greenschists (2) and the flysch (1). The major outcrop of hangingwall rocks is located at Roukounas area and comprises acid intrusives of unit 5 (Fig 5a).

Shearing within the top of the footwall flysch and development of low-angle SW-dipping anastomosing fault surfaces bearing dip-slip striations truncate the alpine microstructures (b-folds and axial-planes Fig 5b).

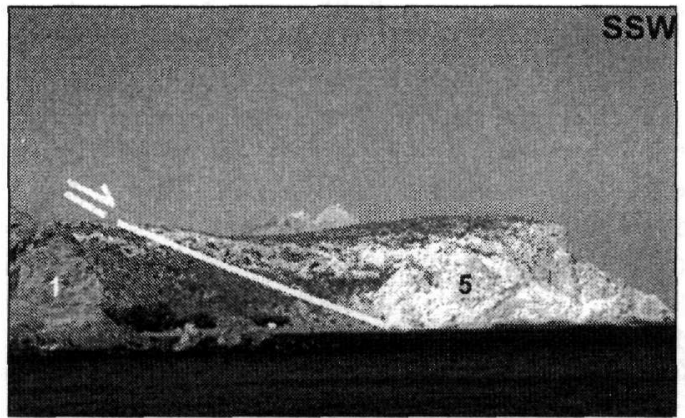

Figure 5a. Low-angle normal fault in Roukounas area (see fig1). Granitic rocks of unit 5 (right, light-color) juxtaposed against the flysch of unit 1 (left, dark color).

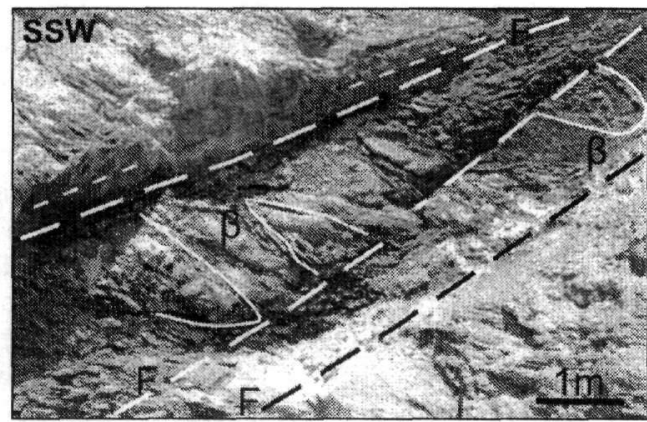

Figure $5 \mathrm{~b} . \mathrm{D}_{2}$ low-angle normal fault surfaces $(F)$ dipping $S W$ deform $D_{1} \beta$-folds and axial planes in the flysch. 


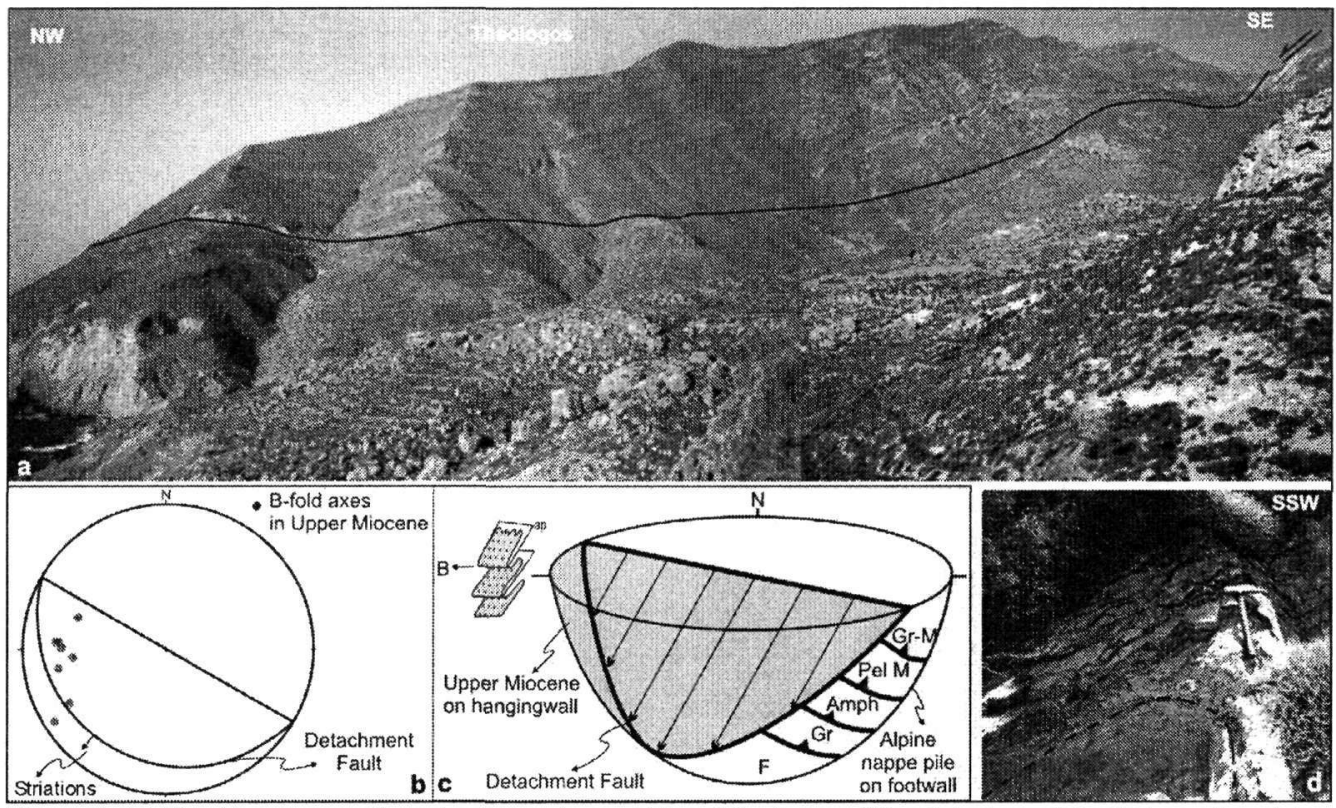

Figure 6. (a) The Neogene sediments at Theologos Hill and the trace of the detachment fault above the alpine units. (b) Stereographic projection of the detachment fault and the WSW plunging B-fold axes of the upper Miocene sediments. c) Schematic fault diagram of the detachment fault plane separating the underlying thrusts of the alpine nappe pile from the overlying folded upper Miocene sediments. d) South-southwest verging E-W asymmetric fold in the upper Miocene sediments.

The NW-SE trending main detachment normal fault comprises Upper Miocene sediments in the hanging wall and alpine formations in the footwall (Fig. 6a). A sharp surface is observed at the northern slope of Theologos Hill separating the Upper Miocene sediments from a several meters thick zone of ankeritic rocks, gauge and breccia comprising both alpine (granitic rocks of unit 5) and post-alpine clasts. Kinematic indicators were observed in the fault zone and the fault surface including rotated clasts with asymmetric tails in the cataclastic rocks, striations on the detachment surface as well as asymmetric folds in the Upper Miocene sediments all indicating transport direction towards the SW (Fig. 6b-c).

The emergence of alpine basement rocks in NW-SE ridges indicates that the fault surface is undulated (horse structure). Above the detachment the deformation of the Upper Miocene sediments is rather complicated with south-southwest verging folds (Fig. 6d) and associated local reverse faults. Several NW-SE trending high-angle normal faults cause tilting of the Neogene sediments towards the NE and SW producing local angular unconformities. These faults are genetically and kinematically related to the detachment fault since they do not affect the underlying alpine units.

At the southern coast the lowermost horizons of the Upper Miocene sediments show intense shear deformation with microstructures indicating top-to-SW sense of shear and dip steeply $\left(35^{\circ}\right.$ $40^{\circ}$ ) towards the southwest almost sub-parallel to the detachment fault surface. Towards the west deformation progressively diminishes and the upper part of the Upper Miocene - ?Lower Pliocene sediments gradually becomes subhorizontal.

At the western coast, within the intensely sheared "molasse" SW-dipping cleavage surfaces, geometrically and kinematically similar to those observed along the southern coast in the flysch, truncate bedding and enclose clasts with asymmetric tails indicating top-to-SW sense of shear.

\subsection{Post-alpine structures}

High angle normal faults cut through both alpine $\left(D_{1}\right)$ and late-alpine $\left(D_{2}\right)$ structures. Two main fault sets trending generally NW-SE and NE-SW are observed (deformation phase $D_{3}$ ). The NW-SE 
high-angle normal faults present similar geometric and kinematic characteristics to some NW-SE minor splay faults of the late-alpine low-angle normal faults. Therefore, it is difficult to distinguish them unless they offset the previous late-alpine structures. NE-SW faults are less in number but they control part of the southeastern coastline.

At the southern part of the island both fault sets downthrow the alpine and post-alpine sediments towards the S-SW as indicated by striations on slickensides (Fig 7). It is noteworthy that although the direction of these two fault sets is almost orthogonal, their slip direction is about the same $\left(200^{\circ}-215^{\circ}\right.$ azimuth). These younger faults produce tilting of both alpine thrust faults and late-alpine low-angle normal faults especially at the eastern part of Anafi Island where thrusts and S-surfaces are dipping very steeply towards the NE and create a NW-SE asymmetric horst of Anafi Island. Although these two sets crosscut each other the NW-SE trending faults may be slightly older following the subparallel previous low-angle normal faults of $D_{2}$

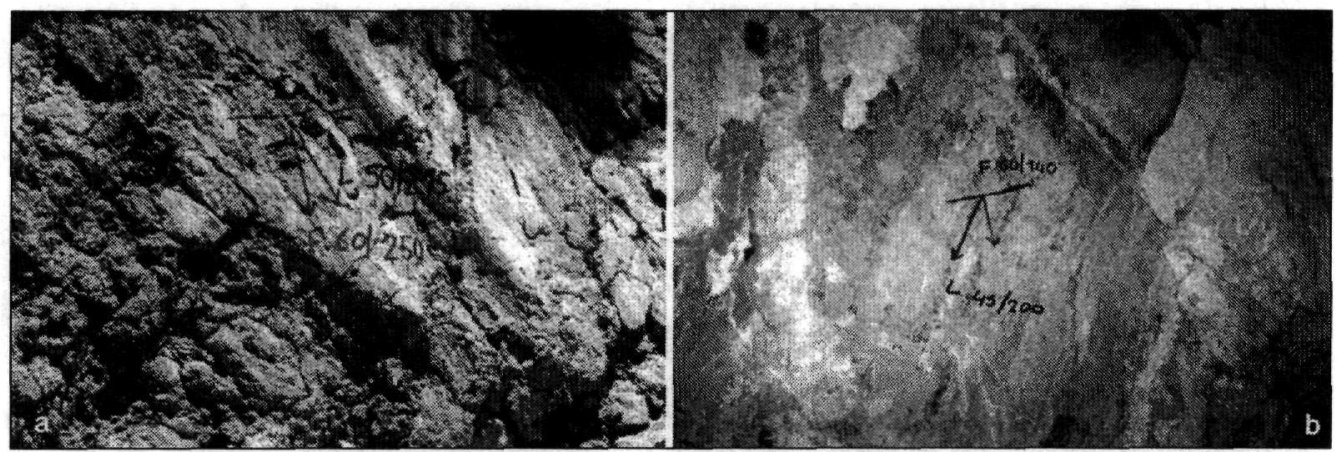

Figure 7a-b. SSW slip direction (azimuth $200^{\circ}-215^{\circ}$ ) observed at the southern coast in both NW-SE trending (a) and NE-SW trending (b) high-angle normal faults of deformation phase $D_{3}$.

\section{DISCUSSION}

Three deformation phases can be distinguished in Anafi Island on the basis of the major brittle deformation structures: alpine thrust faults in deformation phase $D_{1}$, late-alpine low-angle normal faults in deformation phase $D_{2}$ and post-alpine high-angle normal faults in deformation phase $D_{3}$.

$D_{1}$ alpine contractional deformation phase comprises N-NE dipping thrust faults that separate the alpine units of Anafi Island with top-to-the-S-SW tectonic transport. WNW-ESE tight to isoclinal folds and mesoscopic scale thrust faults parallel to the major alpine thrusts are observed in the parautochthonous partly Eocene flysch. $D_{1}$ alpine thrusts were formed at a shallow tectonic level as indicated by the type of cataclastic rocks (mostly tectonic breccia and occasionally foliated cataclasites) observed along these contacts. The $D_{1}$ tectonic emplacement of the metamorphosed alpine units over the partly Eocene flysch and the associated structures of deformation phase $D_{1}$ took place probably during Oligocene - Early Miocene in a fore-arc to island-arc geotectonic environment (Fig 8a).

$\mathrm{D}_{2}$ extensional deformation phase comprises the low-angle normal faults that affect the alpine units and the alpine thrusts as well as the detachment faults at the base of the late and post-alpine sediments. This deformation phase $D_{2}$ is associated with the collapse of the previously formed alpine nappe pile and includes low-angle normal faults dipping to the S-SW (Fig 8b). Asymmetric folding towards the S-SW and angular unconformities within the Upper Miocene sediments belong to this phase $D_{2}$.

The detachment fault at the western part of the island is associated with synextensional sedimentation. Thus, the basal truncation of the sedimentary sequence along the detachment and the folding are observed at the lower part of the sediments. On the contrary, towards the upper part the deformation diminishes and the higher $100 \mathrm{~m}$ are slightly dipping to the SW with less than $10^{\circ}$. This difference in deformation between the lower and the upper part of the Upper Miocene sediments 
shows that the detachment became inactive during the sedimentation. Thus, the extensional latealpine phase $D_{2}$ should be active during ?Middle-Late Miocene.
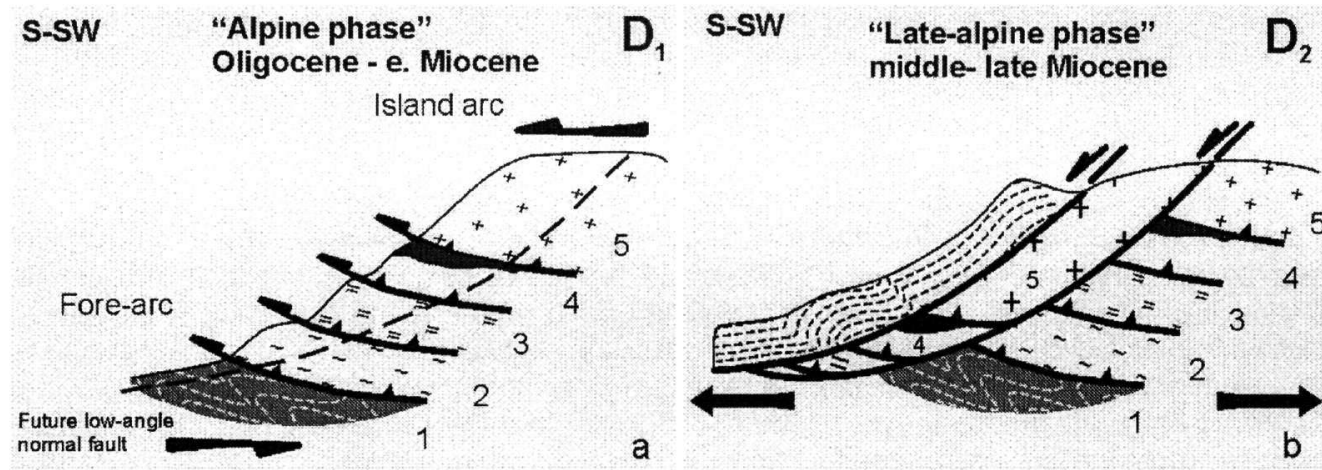

S-SW

"Post-alpine phase"
Late Miocene - Pliocene
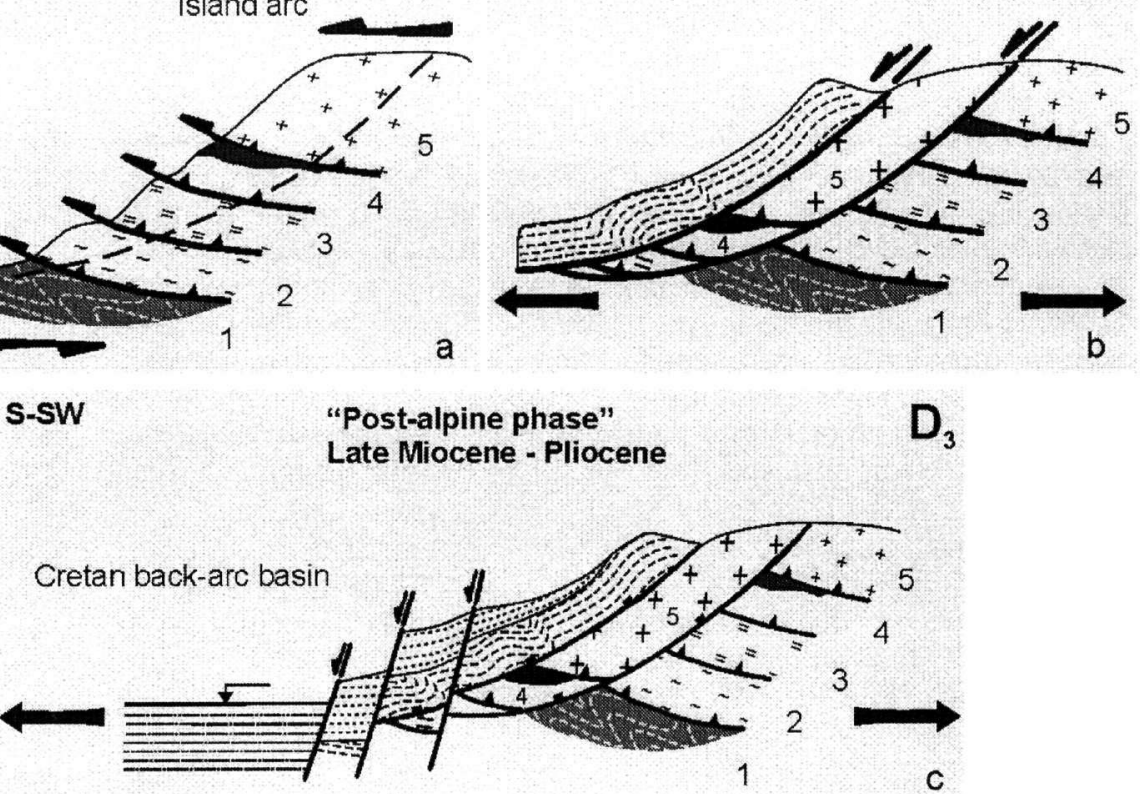

Figure 8. Model proposed for the evolution of the geological structure of Anafi Island. a) Thrust faults formed during Alpine $D_{1}$ contractional deformation phase creating a nappe pile of metamorphic units over a nonmetamorphic parautochthonous flysch b) Late-alpine $D_{2}$ extensional deformation phase resulted in the development of low-angle normal faults and detachments between the upper Miocene sediments and the alpine units c) $D_{3}$ high-angle normal faults offset both alpine and late-alpine structures and contribute to the formation of the Cretan back-ark basin during Late Miocene-Pliocene. NNE-SSW direction of tectonic transport during both the contractional $D_{1}$ and the extensional deformation phases $D_{2}$ and $D_{3}$ remained constant.

Similar major extensional structures have been reported in other Cycladic islands both in metamorphic units (e.g. los Forster \& Lister 1999) or between the upper non-metamorphic Cycladic nappe and the underlying metamorphic units involving also the allochthonous Early Miocene Cycladic molasse (Papanikolaou 1980a,b, 1987). The type of cataclastic rocks observed along the low-angle normal faults e.g. ankeritic rocks and occasionally foliated cataclasites and the fact that they affect Upper Miocene sediments indicate that they possess a higher structural position in the Aegean detachments.

$\mathrm{D}_{3}$ deformation phase comprises NW-SE and NE-SW trending high-angle normal faults (fig 8c). NW-SE trending high-angle normal faults of $D_{3}$ produce down throw of the alpine and post-alpine sediments towards the S-SW which is kinematically similar to the $\mathrm{D}_{2}$ deformation phase. Taking into account the geotectonic position of Anafi Island at the northern edge of the Cretan back-ark basin, we consider $D_{2}$ and $D_{3}$ distinct parts of a continuous process that resulted in the formation of the Cretan back-arc basin, whose opening started during Tortonian and continued in the Pliocene (Jongsma et al 1977, LePichon \& Angelier 1979, 1981, LePichon et al. 1982).

\section{CONCLUSIONS}

Alpine compressional deformation including thrusting, folding and formation of cataclastic zones has occurred in the Anafi nappe pile during Oligocene-Early Miocene $\left(D_{1}\right)$. The geometry of these planar structures is dipping to the N-NE with emplacement towards the S-SW. Both the non- 
metamorphosed relative autochthon flysch and the nature of the cataclastic fault rocks indicate a shallow tectonic level in the upper crust.

Late-alpine extensional deformation including low-angle normal faults and detachment of the molassic and post-alpine sediments over the alpine units has occurred during Middle to Late Miocene $\left(D_{2}\right)$. The geometry of the new planar structures is dipping to the S-SW - opposite to that of the previous thrusts - with a direction of tectonic transport towards S-SW. Folding and brittle structures within and at the base of the Upper Miocene sediments indicates the synsedimentary nature of this late-alpine deformation phase.

Intense shearing has been developed at the intermediate tectonic slices of the molassic sediments involved along the main detachments. Considering the Early Miocene age of the Cycladic molasse in other islands (e.g. Paros Papanikolaou 1980a) the deformation phase $D_{2}$ should have started in Middle Miocene. The absence of deformation structures at the upper part of the post alpine sediments indicates the end of this phase during Late Miocene.

Extensional post-alpine deformation including high-angle normal faults affecting all previous structures has occurred during Late Miocene - Pliocene $\left(D_{3}\right)$. The oblique-slip normal faults of this phase are from the kinematic viewpoint similar the low-angle normal faults of deformation phase $D_{2}$ with downthrow towards S-SW (slip direction around $200^{\circ}-220^{\circ}$ azimuth).

Both extensional deformation phases $D_{2}$ and $D_{3}$ of Anafi Island should be related to the opening of the Cretan Sea as a new back-arc basin of the Hellenic arc during Tortonian - Pliocene.

\section{AGKNOWLEDGEMENTS}

The authors would like to thank Prof. L. Royden (M.I.T.) for stimulating discussion in the field during summer 2002. Dr loannis Papanikolaou and two anonymous reviewers helped improving the manuscript with their careful and constructive comments.

\section{REFERENCES}

Angelier, J., Lyberis, N., Le Pichon, X., Barrier, E. \& Huchon, P. 1982. The tectonic development of the Hellenic Arc and the Sea of Crete: a synthesis. Tectonophysics 86, 159-196.

Boger, H. 1983. Das Statigraphische und tektonische Verknüpfungen kontinentaler Sedimente des Neogen im Agais-Raum, Geol. Rdsch 72, 771-814.

Dermitzakis, M. \& Papanikolaou, D. 1981. Paleogeography and Geodynamics of the Aegean Region during the Neogene. VII Int. Congress Medit. Neogene, Athens 1979, Ann. Geol. Pays Hellen., hors serie IV, 245-289.

Forster, M. A. \& Lister, G. S. 1999. Detachment faults in the Aegean core complex of los, Cyclades, Greece. In: Ring, U., Brandon, M. T., Lister, G. S., \& Willett, S. D. (eds.). Exhumation Processes: Normal Faulting, Ductile Flow and Erosion. Geological Society Special Publications 154, 305-324.

Jongsma, D., Wismann, G., Hinz, K. \& Garde, S. 1977. Seismic studies in the Cretan Sea. 2. The Southern Aegean Sea: An extensional marginal basin without seafloor spreading? Meteor. Forsch. Ergebnisse, C, 27, 330.

Le Pichon, X. \& Angelier, J. 1979. The Hellenic Arc and Trench system: a key to the neotectonic evolution of the Eastern Mediterranean area. Tectonophysics 69, 1-42.

Le Pichon, X. \& Angelier, J. J. 1981. The Aegean Sea. Phil. Trans. R. Sot. 300, 357-372.

Melidonis, N. 1963. Die Geologie der insel Anafi, Athens, Geological and Geophysical Research 8 (3), $53-308$.

Papanikolaou D., 1980a. Contribution to the geology of the Aegean Sea. The island of Paros. Ann. Geol. Pays Hellen., 30/1, 65-96.

Papanikolaou D., 1980b. Les écailles de Thymaena; témoins d'un mouvement tectonique vers l'intérieur de l'arc égéen. C.R.Acad. Sc. Paris, 290, 3-7-310.

Papanikolaou, D., 1987. Tectonic evolution of the Cycladic blueschist belt (Aegean Sea, Greece). In: Chemical Transport in Metasomatic Processes, Reidel. Publ., 429-450.

Reinecke, T., Altherr. R., Hartung. B.. Hatzipanagiotou. K., Kreuzer, H., Harre, W., Klein. H., Keller, J., Geenen, E. \& Boger, H. 1982. Remnants of late Cretaceous high temperature belt on the island of Anafi (Cyclades, Greece). Neus Jahrbuch fur Mineralogie Abhandlungen 145, 157-182. 